\title{
On the category of near-rings
}

\section{MARIANA DUMitru, LAURA NĂSTĂSESCU and BOGDAN TOADER}

\section{ABSTRACT.}

We consider the category of near-rings and study some categorical permanence properties. We investigate the connection between the concepts of monomorphism and, respectively, epimorphism of near-rings and the concepts of injective and, respectively, surjective morphism of near-rings. We also present some interesting properties of epimorphisms in the category of near-rings.

Acknowledgements. The authors wish to thank the referees for their careful reading of the manuscript and for their useful comments. The research of Laura Năstăsescu was supported by grant ID_0635, contract no. 253/15.10.2011 of C.N.C.S.I.S.

\section{REFERENCES}

[1] Balbes, R. and Dwinger, P., Distributive Lattices, University of Missouri Press, Missouri, 1974

[2] Dăncescu, S. and Năstăsescu, C., Special Topics in Algebra (in Romanian), University of Bucharest Press, Bucharest, 1982

[3] Gutierrez, J. and Ruiz De Velasco Y Bellas, C., Distributive elements in the near-rings of polynomials, Proc. Edinburgh Math. Soc., 32 (1989), 73-80

[4] Pilz, G., Near-Rings: The Theory and Its Applications, Revised Edition, North Holland Publishing Co., Amsterdam, 1983

[5] Rotman, J. J., Introduction to the Theory of Groups, 4th Edition, Springer-Verlag, New York, 1995

MARITIME UNIVERSITY OF CONSTANŢA

FACULTY OF NAVIGATION AND NAVAL TRANSPORT

Mircea CEL BĂTRÂN 104, RO-900663, CONSTANŢA, ROMANiA

E-mail address: darianax@gmail.com

UNIVERSITY OF BUCHAREST

Algebra AND Number THEORY RESEARCH CENTER

ACADEMIEI 14, RO-010014, BUCHAREST 1, ROMANIA

E-mail address: lauranastasescuegmail.com

"Dimitrie CANTEMIR" CHRISTIAN UNIVERSITY

FACULTY OF TOURISTIC AND COMMERCIAL MANAGEMENT

SPLAIUL UNIRII 176, RO-030134, BUCHAREST 4, ROMANIA

E-mail address: bogdantdeyahoo.com

Received: 14.09.2013; In revised form: 28.01.2014; Accepted: 23.04.2014

2010 Mathematics Subject Classification. 16Y30.

Key words and phrases. Near-ring, category of near-rings, monomorphism, epimorphism.

Corresponding author: Bogdan Toader; bogdantd@yahoo.com 